BUSO, W.H.D. et al. Utilização do sorgo forrageiro na alimentação animal. PUBVET, Londrina, V. 5, N. 23, Ed. 170, Art. 1145, 2011.

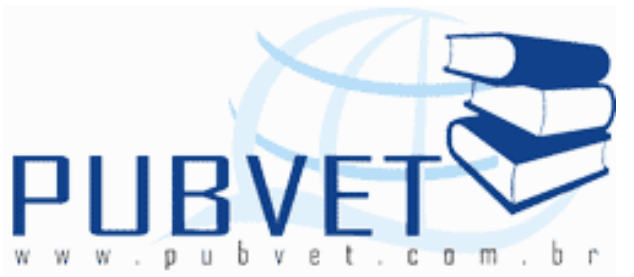

PUBVET, Publicações em Medicina Veterinária e Zootecnia.

\title{
Utilização do sorgo forrageiro na alimentação animal
}

Wilian Henrique Diniz Busoㅇ, Hélber Souto Morgado1, Luciana Borges e Silva², Aldi Fernandes de Souza França ${ }^{3}$

${ }^{1}$ Aluno de doutorado da Escola de Veterinária da Universidade Federal de Goiás (EV/UFG) (wilianbuso@yahoo.com)

${ }^{2}$ Professora Dra. do IFGoiano - Campus Ceres

${ }^{3}$ Professor Dr. da EV/UFG

\section{Resumo}

A cultura do sorgo desempenha grande importância dentro do sistema de produção da bovinocultura brasileira, por possuir resistência ao déficit hídrico, crescimento rápido e emissão de perfilhos. É uma cultura com altas taxas fotossintéticas e rápido alongamento de colmos, assim, é utilizado para a fabricação de silagem e pastejo direto. Esta cultura apresenta alta capacidade de produção de volumoso para utilização em períodos de baixa produção das pastagens nativas ou manejadas. A silagem de sorgo apresenta alta qualidade capaz de atender as necessidades nutricionais dos animais.

\section{Use in animal feed forage sorghum}

\section{Abstract}

The sorghum crop plays a great importance in the production system of the Brazilian cattle industry, because it has resistance to drought, rapid growth 
BUSO, W.H.D. et al. Utilização do sorgo forrageiro na alimentação animal. PUBVET, Londrina, V. 5, N. 23, Ed. 170, Art. 1145, 2011.

and issuance of tillers. It is a crop with high photosynthetic rates and rapid stem elongation, and is used for making silage and rotational grazing. This culture has a high capacity to produce forage for use in periods of low production or grazing of native pastures. Sorghum silage has a high quality capable of meeting the nutritional needs of animals.

\section{INTRODUÇÃO}

Vários fatores exercem influência na produção do rebanho bovino brasileiro quando mantido em campo. Destacando-se a quantidade de forragem disponível na pastagem, o consumo de matéria seca da forrageira pastejada e o valor nutricional da forragem, que são características dependentes, em grande parte, do manejo da forrageira (MACHADO 2010).

O sorgo [Sorghum bicolor (L.) Moench] é uma cultura que no contexto da agropecuária brasileira vem se destacando a cada dia, por ser uma gramínea bastante energética, com alta digestibilidade, produtividade e adaptação a ambientes secos e quentes, nos quais é difícil o cultivo de outras espécies. A planta é utilizada para silagem ou corte verde, para pastejo e os grãos, em rações animais e para o consumo humano.

Visando aumentar a produtividade da bovinocultura durante o verão, podem-se fazer uso de pastagens cultivadas de estação quente. Em função do crescente processo de verticalização da atividade pecuária brasileira, apresentam-se como uma alternativa estratégica à sustentabilidade e eficiência de uso da terra em sistemas de recria e engorda de bovinos em pastejo (NEUMANN et al., 2005).

A qualidade das pastagens está diretamente ligada às características da organização estrutural. Os microrganismos que habitam o rúmen possuem a capacidade de digerir a celulose e não a lignina. Como a estrutura do vegetal contém tanto celulose como lignina, diferenças na proporção de tecidos com lignina influenciam na qualidade das forragens (SILVA et al., 2005). 
BUSO, W.H.D. et al. Utilização do sorgo forrageiro na alimentação animal. PUBVET, Londrina, V. 5, N. 23, Ed. 170, Art. 1145, 2011.

O período de utilização das gramíneas pode ser fortemente influenciado pelo manejo, corte ou pastejo, e também pelas características climáticas, pois são culturas anuais, cuja produção é afetada pelo fotoperíodo e temperatura (MONTAGNER et al., 2005).

Diante destas necessidades, a cultura do sorgo pode ser de grande importância para os sistemas de produção da bovinocultura brasileira, por ser resistente ao déficit hídrico e apresentar acelerado crescimento e emissão de perfilhos. Quando a umidade do solo é suficiente, essa cultura possui altas taxas fotossintéticas e rápida elongação de colmos, dessa forma, é utilizado para a fabricação de silagem e pastejo direto.

Assim, este trabalho teve o objetivo de fazer uma revisão de literatura sobre uso do sorgo na alimentação animal.

\section{REVISÃO DE LITERATURA}

\section{Caracterização da espécie}

\section{Origem e classificação botânica}

O sorgo tem sido uma excelente opção para produção de diversas formas, como planta forrageira para pastoreio e silagem, produção de grãos para fabricação de ração e planta de cobertura do solo para o sistema de planto direto. Adapta-se a situações de déficit hídrico e às condições de baixa fertilidade dos solos que oferecem maiores riscos a outras culturas (RIBAS, 2010).

O sorgo pertence à família Poaceae, gênero Sorghum e a espécie cultivada é Sorghum bicolor (L.) Moench. É originário de regiões de clima tropical provavelmente da África, mas algumas evidências indicam que possa ter ocorrido duas regiões de dispersão independentes: África e Índia. A planta não suporta baixas temperaturas e por isso, no Brasil, é cultivado em regiões e situações de temperaturas médias superiores a $20^{\circ} \mathrm{C}$ (RIBAS, 2008). 
BUSO, W.H.D. et al. Utilização do sorgo forrageiro na alimentação animal. PUBVET, Londrina, V. 5, N. 23, Ed. 170, Art. 1145, 2011.

O sorgo é uma planta que, na maioria necessita de temperaturas acima de $20^{\circ} \mathrm{C}$ para seu crescimento e desenvolvimento, permitindo assim que a cultura seja apta a se desenvolver e expandir em regiões de cultivo com distribuição irregular de chuvas e em sucessão à culturas de verão, elevada produção de massa a ser ensilada e à alta capacidade de rebrote (RODRIGUES FILHO et al., 2006).

\section{Importância econômica}

De acordo com RIBAS (2008), o sorgo é cultivado em áreas e situações ambientais muito secas e/ou muito quentes, onde a produtividade de outros cereais é anti econômica. Embora de orígem tropical, o sorgo vem sendo cultivado em latitudes de até $45^{\circ}$ norte ou $45^{\circ}$ sul, e isso só foi possível graças aos trabalhos dos melhoristas de plantas, que desenvolveram cultivares com adaptação fora da zona tropical. Sorgo é cultivado principalmente onde a precipitação anual se situa entre 375 e 625 mm ou onde esteja disponível irrigação suplementar.

É, entre as espécies alimentares, uma das mais versáteis e mais eficientes, tanto do ponto de vista fotossintético, como em velocidade de maturação. Sua reconhecida versatilidade se estende desde o uso de seus grãos como alimento humano e animal; como matéria prima para produção de álcool anidro, bebidas alcoólicas, colas e tintas; o uso de suas panículas para produção de vassouras; extração de acúcar de seus colmos; até às inúmeras aplicações de sua forragem na nutrição de ruminantes (RIBAS, 2008).

O sorgo granífero é o que tem maior expressão econômica e está entre os cinco cereais mais cultivados em todo o mundo, ficando atrás do arroz, trigo, milho e cevada. A área total cultivada com sorgo granífero é de cerca de 37 milhões de ha, e deste total Asia e Africa participam com 82\%. No entanto, a maior produção e produtividade estão na América do Norte. Estados Unidos e México juntos produzem 34\% da produção mundial. Entre os maiores

produtores de grãos de sorgo do mundo, a Índia detém a maior área plantada, com cerca de 11 milhões de ha. Mas os Estados Unidos lideram a produção 
BUSO, W.H.D. et al. Utilização do sorgo forrageiro na alimentação animal. PUBVET, Londrina, V. 5, N. 23, Ed. 170, Art. 1145, 2011.

mundial, com quase 14 milhões de t numa área de pouco mais de 3 milhões de ha. Na América do Sul, Argentina é o maior produtor, seguido pelo Brasil. A produção brasileira está crescendo rapidamente e poderá, ainda nesta década, se igualar ou superar a posição da Argentina no Continente (RIBAS, 2008).

\section{Variedades de sorgo}

Agronomicamente os sorgos são classificados em 4 grupos: granífero; forrageiro para silagem e/ou sacarino; forrageiro para pastejo/corte verde/fenação/cobertura morta; vassoura. O primeiro grupo inclui tipos de porte baixo (híbridos e variedades) adaptados à colheita mecânica. O segundo grupo inclui tipos de porte alto (híbridos e variedades) apropriados para confecção de silagem e/ou produção de açúcar e álcool. O terceiro grupo inclui tipos utilizados principalmente para pastejo, corte verde, fenação e cobertura morta (variedades de capim sudão ou híbridos inter específicos de Sorghum bicolor $\times$ Sorghum sudanense). O quarto grupo inclui tipos de cujas panículas são confeccionadas vassouras (RIBAS, 2008).

As cultivares diferem pela altura de plantas, quantidades de colmo, folhas e panículas, o que reflete na produtividade, composição bromatológica e valor nutritivo. O sorgo granífero que é cultivado para produção de grãos possui porte baixo. Quando usado para silagem a produção de massa verde é baixa. As cultivares forrageiras possuem porte de 2 a 3 metros de altura e são adaptadas para corte verde e produção de silagem, apresentando alto rendimento de massa verde. Os híbridos de duplo propósito possuem porte médio, de 2,0 a 2,5 metros, utilizados para grãos e forragem, alta produção de massa verde e grãos que conferem alta qualidade da silagem (COELHO, 1979).

\section{Semeadura e adubação}

As sementes de sorgo são de tamanho reduzido, assim a profundidade de semeadura deve ser de 3 a $5 \mathrm{~cm}$ a fim de facilitar a emergência e estabelecimento do estande adequado de plantas. A época de semeadura depende do clima de cada região. Na Região Centro-Oeste, a 
BUSO, W.H.D. et al. Utilização do sorgo forrageiro na alimentação animal. PUBVET, Londrina, V. 5, N. 23, Ed. 170, Art. 1145, 2011.

semeadura de verão é realizada de outubro a dezembro e a safrinha a partir de fevereiro (VIANA et al., 2001). O espaçamento de semeadura pode variar de acordo com o porte da planta e aptidão. Em cultivares forrageiras de porte alto, o espaçamento pode variar de 0,70 a 0,90 m, com população variando de 120 a 140 mil plantas ha ${ }^{-1}$. O ciclo da planta varia de 80 a 180 dias, conforme a finalidade do cultivo.

A semeadura pode ser em linha ou a lanço. Em linha, gastam-se de 10 a $12 \mathrm{~kg} \mathrm{ha}^{-1}$ de sementes. O sorgo pode ser utilizado para corte ou silagem. A lanço, o consumo de sementes é de 20 a $30 \mathrm{~kg} \mathrm{ha}^{-1}$ de sementes e a população pode chegar a 600 mil plantas ha-1 (RIBAS, 2008).

De acordo com SOUSA \& LOBATO (2004) a adubação no sulco de semeadura devem-se levar em consideração os resultados da análise de solo, as dosagens de $\mathrm{N}_{1} \mathrm{P}_{2} \mathrm{O}_{5}$ e $\mathrm{K}_{2} \mathrm{O}$ são: $20 \mathrm{~kg} \mathrm{ha}^{-1}, 30$ a $80 \mathrm{~kg} \mathrm{ha}^{-1}$ e 20 a $60 \mathrm{~kg} \mathrm{ha}$ 1 , respectivamente. A adubação nitrogenada em cobertura pode variar de 30 a $110 \mathrm{~kg} \mathrm{ha}^{-1}$ de $\mathrm{N}$. As quantidades de $\mathrm{N}$ devem ser reduzidas quando o sorgo for cultivado em área com baixo potencial de resposta a este nutriente.

\section{Outras particularidades}

À capacidade de rebrote, do sorgo é uma característica vantajosa. Fatores de manejo da cultura afetam o perfilhamento, como a população de plantas. Quanto menor a população, maior a possibilidade de perfilhamento. Em dias curtos e temperaturas mais baixas ocorre aumento no perfilhamento das plantas. Quaisquer danos no ponto de crescimento da planta pode levar a acelerar o processo de perfilhamento, danos estes, que podem ser causados por insetos, estresse severo de água ou temperatura (MAGALHÃES et al., 2003). À medida que o estádio de maturação avança, há aumento na quantidade de amido no grão, resultante da conversão de carboidratos solúveis que estavam armazenados no colmo, assim ocorre aumento nos teores de FDN, FDA e lignina no colmo. 
BUSO, W.H.D. et al. Utilização do sorgo forrageiro na alimentação animal. PUBVET, Londrina, V. 5, N. 23, Ed. 170, Art. 1145, 2011.

\section{Tanino: características e efeitos}

Os taninos são compostos fenólicos com grupos hidroxifenólicos para formarem efetivos e fortes complexos com proteínas e outras macromoléculas (celulose, amido, minerais), tornando-as indisponíveis. A maior parte do tanino presente na planta de sorgo encontra-se no grão, sob a forma de protocianidinas (MAGALHÃES et al., 1997). Atualmente considera-se que o tanino está presente, quando são encontrados níveis acima de $0,7 \%$, ou ausente, quando são encontrados níveis abaixo de 0,7\%, nos grãos, utilizandose o método Azul da Prússia para quantificar este composto. Agronomicamente o tanino tem as vantagens de resistência a pássaros, a fungos causadores de podridão de grãos, redução de germinação de grãos na panícula e resistência a insetos no período inicial de crescimento da planta, mas causa reduções na palatabilidade e digestibilidade por formar complexos com proteínas.

Os taninos podem provocar reduções no valor nutritivo das forragens para ruminantes através do menor consumo e disgestibilidade de proteínas, carboidratos e desempenho animal. A facilidade dos taninos de formar complexos fortes com proteínas é o principal aspecto relacionado aos seus efeitos tóxicos e antinutricionais. Também pode interagir com carboidratos, principalmente o amido. A redução da digestibilidade de dietas ricas em taninos pode também ser explicada pela inibição das enzimas digestivas. Os efeitos dos taninos sobre os microrganismos ruminais são muito variáveis, sendo alguns altamente sensíveis e outros resistentes e capazes de degradálos (JASMAN, 1993).

PIRES et al. (2009) observaram que 0 tanino influenciou negativamente a degradabilidade ruminal das fibras FDN e FDA quando compararam cultivares de sorgo com presença e ausência deste composto fenólico. Assim a presença de tanino na silagem de sorgo compromete a degradabilidade da fração fibrosa, onde exerce redução na degradação da fibra.

A presença de tanino nos alimentos tem provocado redução na degradação da MS pela inibição das enzimas digestivas e inibição do 
BUSO, W.H.D. et al. Utilização do sorgo forrageiro na alimentação animal. PUBVET, Londrina, V. 5, N. 23, Ed. 170, Art. 1145, 2011.

crescimento microbiano. Os teores de proteína também ocorreram redução na sua degradação quando o tanino esta presente nos alimentos. As cultivares de sorgo com tanino apresentaram menores valores de degradabilidade da MS e PB in vitro (MOLINA et al., 2003).

\section{Mutação BMR (Brown-midrib)}

As plantas mutantes BMR (portadores de nervura marrom) são fenotipicamente caracterizadas pela presença de pigmentos amarronzados na nervura central das folhas e no colmo. Estes pigmentos estão fortemente associados à lignina, pois persistem na parede celular após a remoção de celulose e hemiceluloses. O fenótipo BMR é característico de plantas diplóides e pode ocorrer de forma espontânea na natureza ou ser provocado por engenharia genética (BARRIÈRE et al., 2004).

A mutação no sorgo foi provocada a partir do tratamento químico das sementes com di-etil sulfeto. A partir desse tratamento foram gerados 19 mutantes BMR de ocorrência independente identificados em progênies segregadas. Alguns desses mutantes apresentam redução significativa do conteúdo de lignina e aumento da digestibilidade da parede celular. A partir destes 19 genes foram selecionados três de melhores características agronômicas (bmr-6, bmr-12 e bmr-18) (FRITZ et al., 1988).

CASLER et al. (2003) avaliaram as alterações provocadas pela mutação bmr-6 em dois diferentes cultivares de capim-sudão. Os fenótipos BMR apresentaram aumento no valor nutricional quando comparados aos materiais normais, porém, a produtividade foi reduzida. No primeiro corte, na média dos locais, dos anos agrícolas e das cultivares utilizadas, a redução na produtividade foi de aproximadamente $15 \%$ e no segundo corte (rebrote) foi ainda maior, de 30\%. Outras características agronômicas como: capacidade de rebrote, porcentagem de germinação e altura de planta também foram reduzidas significativamente pela mutação BMR.

Alguns mutantes BMR também apresentam melhor palatabilidade. Mesmo em experimentos com curto período de pastejo, durante o qual a 
BUSO, W.H.D. et al. Utilização do sorgo forrageiro na alimentação animal. PUBVET, Londrina, V. 5, N. 23, Ed. 170, Art. 1145, 2011.

digestibilidade não é o fator primordial para a avaliação da ingestão, os ovinos tendem a escolher o híbrido de sorgo mutante BMR quando plantados lado a lado ao híbrido normal. A razão para essa preferência de pastejo não é clara. É possível que algum fator sensorial no material BMR o torna mais palatável e mais atrativo ao animal. Seja qual for a razão, essa maior aceitação pelos animais pode aumentar o valor nutricional das plantas mutantes BMR, por ter o potencial de aumentar o consumo (RIBAS, 2010).

RIBAS (2010) avaliou vinte e cinco híbridos de sorgo com capimsudão, normais e mutantes BMR, avaliados aos 51 dias após o plantio e aos 31 dias de rebrota e observou que a altura das plantas nos dois cortes foi superior nos híbridos normais e menor nos mutantes BMR. A DIVMS dos mutantes BMR foi em média $7 \%$ acima dos híbridos normais. A PB foi $10,7 \%$ superior nos mutantes BMR. O maior teor de PB nos mutantes, não pode ser creditado apenas aos efeitos da mutação e sim à diferença de acúmulo de MS observado entre os híbridos avaliados. Comparado à várias fontes forrageiras, os híbridos de sorgo com capim-sudão podem ser considerados excelentes alimentos volumosos para a suplementação de ruminantes devido ao alto consumo e alta digestibilidade de suas frações fibrosas.

\section{COMPOSIÇÃO BROMATOLÓGICA}

Trabalhando com três idades de cortes diferentes MACHADO (2009) observou comportamentos diferentes na porcentagem de folha, colmo e panícula à medida que aumenta a idade de corte (Tabela 1) e decréscimo na produção de massa verde à medida que avançou os estádios de maturação (Tabela 2). As porcentagens de folhas e colmo reduziram com o avanço dos estádios de maturação, enquanto na porcentagem de panícula ocorreu acréscimo a medida que o estádio de maturação avançou, pois há translocação intensa de nutrientes das partes vegetativas para a formação dos grãos. Este acréscimo na participação da panícula é desejável, já que representa a fração de maior valor nutritivo. 
BUSO, W.H.D. et al. Utilização do sorgo forrageiro na alimentação animal. PUBVET, Londrina, V. 5, N. 23, Ed. 170, Art. 1145, 2011.

Conforme MACHADO (2009) a redução na produção de matéria verde deu-se pelo fato de ocorrer maior acúmulo de nutrientes, aumentou o teor de matéria seca e redução do teor de água. Na Tabela 3 estão os valores de matéria seca. Observa-se que para todos os híbridos ocorreu aumento significativo de matéria seca no estádio de maturação farináceo. O híbrido BR 700 mostrou maior produção de matéria seca que os demais híbridos em todos os estádios de maturação. Resultados semelhantes de matéria seca foram observados por EVANGELISTA et al. (2005) quando cortaram o sorgo no estádio de grãos farináceo.

TABELA 1. Porcentagens de folha, colmo e panícula na massa seca de híbridos de sorgo em três estádios de maturação

\begin{tabular}{|c|c|c|c|}
\hline \multicolumn{4}{|c|}{$\%$ de folhas } \\
\hline \multirow{2}{*}{ Híbrido } & \multicolumn{3}{|c|}{ Estádios de maturação } \\
\hline & Leitoso & Pastoso & Farináceo \\
\hline BRS 610 & $20,81 \mathrm{Aa}^{*}$ & $18,31 \mathrm{Ba}$ & $18,37 \mathrm{Aa}$ \\
\hline BR 700 & $22,11 \mathrm{Aa}$ & $21,92 \mathrm{Aa}$ & $16,16 \mathrm{Bb}$ \\
\hline BRS 655 & $15,99 \mathrm{Ba}$ & $16,48 \mathrm{Ba}$ & $14,68 \mathrm{Ba}$ \\
\hline \multicolumn{4}{|c|}{$\%$ de colmo } \\
\hline \multirow{2}{*}{ Híbrido } & \multicolumn{3}{|c|}{ Estádios de maturação } \\
\hline & Leitoso & Pastoso & Farináceo \\
\hline BRS 610 & $54,39 \mathrm{Aa}$ & $45,27 \mathrm{Ab}$ & $39,19 \mathrm{Ac}$ \\
\hline BR 700 & $47,63 \mathrm{Ba}$ & $36,97 \mathrm{Bb}$ & $33,61 \mathrm{Bb}$ \\
\hline BRS 655 & $56,74 \mathrm{Aa}$ & $48,87 \mathrm{Ab}$ & $41,50 \mathrm{Ac}$ \\
\hline \multicolumn{4}{|c|}{$\%$ de panícula } \\
\hline \multirow{2}{*}{ Híbrido } & \multicolumn{3}{|c|}{ Estádios de maturação } \\
\hline & Leitoso & Pastoso & Farináceo \\
\hline BRS 610 & $24,79 \mathrm{~B}$ & $36,43 \mathrm{~B}$ & $42,45 \mathrm{~B}$ \\
\hline BR 700 & $30,27 \mathrm{~A}$ & $41,14 \mathrm{~A}$ & $50,22 \mathrm{~A}$ \\
\hline BRS 655 & $27,27 \mathrm{AB}$ & $34,65 \mathrm{~B}$ & $43,82 \mathrm{~B}$ \\
\hline Média & $27,44 \mathrm{c}$ & $37,40 \mathrm{~b}$ & $45,50 a$ \\
\hline
\end{tabular}

* Médias seguidas de mesma letra maiúsculas nas colunas e minúscula na linha não diferem estatisticamente pelo teste de SNK a 5\%.

FONTE: Adaptado de MACHADO (2010) 
BUSO, W.H.D. et al. Utilização do sorgo forrageiro na alimentação animal. PUBVET, Londrina, V. 5, N. 23, Ed. 170, Art. 1145, 2011.

TABELA 2. Produção de matéria verde em toneladas por hectare de híbridos de sorgos em três estádios de maturação

\begin{tabular}{cccc}
\hline \multirow{2}{*}{ Híbrido } & \multicolumn{3}{c}{ Estádios de maturação } \\
\cline { 2 - 4 } & Leitoso & Pastoso & Farináceo \\
\hline BRS 610 & $68,71 \mathrm{Aa}^{*}$ & $56,99 \mathrm{Ab}$ & $40,40 \mathrm{Ac}$ \\
BR 700 & $47,40 \mathrm{Ba}$ & $34,25 \mathrm{Bb}$ & $31,10 \mathrm{Ab}$ \\
BRS 655 & $43,19 \mathrm{Bb}$ & $54,13 \mathrm{Aa}$ & $39,33 \mathrm{Ab}$
\end{tabular}

* Médias seguidas de mesma letra maiúsculas nas colunas e minúscula na linha não diferem estatisticamente pelo teste de SNK a 5\%.

FONTE: Adaptado de MACHADO (2009)

TABELA 3. Teores de matéria seca (MS) da planta inteira de híbridos de sorgo em três estádios de maturação (\%)

\begin{tabular}{ccccc}
\hline \multirow{2}{*}{ Híbrido } & \multicolumn{4}{c}{ Estádios de maturação } \\
\cline { 2 - 5 } & Leitoso & Pastoso & Farináceo & Média \\
\hline BRS 610 & $25,73 \mathrm{~b}$ & $28,69 \mathrm{a}$ & $30,28 \mathrm{a}$ & $28,23 \mathrm{~B}$ \\
BR 700 & $29,67 \mathrm{c}$ & $39,87 \mathrm{~b}$ & $43,96 \mathrm{a}$ & $37,83 \mathrm{~A}$ \\
BRS 655 & $26,99 \mathrm{~b}$ & $27,39 \mathrm{~b}$ & $31,17 \mathrm{a}$ & $28,52 \mathrm{~B}$
\end{tabular}

Médias seguidas de mesma letra maiúsculas nas colunas e minúscula na linha não diferem estatisticamente pelo teste de SNK a 5\%.

FONTE: Adaptado de MACHADO (2009)

MACHADO (2009) verificou aumento nos teores de matéria seca das folhas em vários híbridos avaliados quando avança os estádios de maturação das plantas. No estádio farináceo ocorreu maior acúmulo de matéria seca em todos os híbridos. Nos colmos não ocorreu diferença significativa dos híbridos nos diferentes estádios de maturação. O hibrido BR 700 apresentou diferença significativa no teor de matéria seca dos colmos em todos os estádios de maturação. Na panícula todos os híbridos obtiveram aumento gradativo no teor de matéria seca com o avanço da maturidade das plantas (Tabela 4). 
BUSO, W.H.D. et al. Utilização do sorgo forrageiro na alimentação animal. PUBVET, Londrina, V. 5, N. 23, Ed. 170, Art. 1145, 2011.

TABELA 4. Teores de matéria seca das folhas, colmos e panículas na massa seca de híbridos de sorgo em três estádios de maturação (\%)

\begin{tabular}{|c|c|c|c|}
\hline \multicolumn{4}{|c|}{ Matéria seca das folhas } \\
\hline \multirow{2}{*}{ Híbrido } & \multicolumn{3}{|c|}{ Estádios de maturação } \\
\hline & Leitoso & Pastoso & Farináceo \\
\hline BRS 610 & $27,50 \mathrm{Ac}^{*}$ & $34,26 \mathrm{Bb}$ & $56,38 \mathrm{Ba}$ \\
\hline BR 700 & $33,30 \mathrm{Ab}$ & $58,44 \mathrm{Aa}$ & $62,18 \mathrm{Aa}$ \\
\hline BRS 655 & $31,27 \mathrm{Ab}$ & $31,56 \mathrm{Bb}$ & $39,22 \mathrm{Ca}$ \\
\hline \multicolumn{4}{|c|}{ Matéria seca dos colmos } \\
\hline \multirow{2}{*}{ Híbrido } & \multicolumn{3}{|c|}{ Estádios de maturação } \\
\hline & Leitoso & Pastoso & Farináceo \\
\hline BRS 610 & $20,71 \mathrm{~B}$ & $19,39 \mathrm{~B}$ & $19,06 \mathrm{~B}$ \\
\hline BR 700 & $26,46 \mathrm{~A}$ & $26,22 \mathrm{~A}$ & $26,24 \mathrm{~A}$ \\
\hline BRS 655 & $22,66 \mathrm{~B}$ & $21,14 \mathrm{~B}$ & $20,45 B$ \\
\hline \multicolumn{4}{|c|}{ Matéria seca das panículas } \\
\hline \multirow{2}{*}{ Híbrido } & \multicolumn{3}{|c|}{ Estádios de maturação } \\
\hline & Leitoso & Pastoso & Farináceo \\
\hline BRS 610 & $39,11 \mathrm{~A}$ & $54,34 \mathrm{~B}$ & $60,25 \mathrm{~A}$ \\
\hline BR 700 & $41,33 \mathrm{~A}$ & $58,00 \mathrm{~A}$ & $61,63 \mathrm{~A}$ \\
\hline BRS 655 & $38,96 \mathrm{~A}$ & $45,43 \mathrm{C}$ & $56,98 \mathrm{~B}$ \\
\hline Média & $39,80 \mathrm{c}$ & $52,59 b$ & 59,62 a \\
\hline
\end{tabular}

* Médias seguidas de mesma letra maiúsculas nas colunas e minúscula na linha não diferem estatisticamente pelo teste de SNK a 5\%.

FONTE: Adaptado de MACHADO (2009)

Segundo MACHADO (2009) os valores de proteína bruta de vários híbridos de sorgo não apresentaram diferenças significativas com o avanço dos estádios de maturação das plantas com valores médios de 5,99\%; 5,70\% e $5,65 \%$ nos estádios leitoso, pastoso e farináceo, respectivamente. 0 mesmo fato ocorreu para o FDN, com valores entre $53,03 \%$ e $57,41 \%$, e para o FDA, que apresentou teores entre $32,16 \%$ e $35,06 \%$, assim o aumento do teor de amido nos grãos compensou o aumento das frações fibrosas. 
BUSO, W.H.D. et al. Utilização do sorgo forrageiro na alimentação animal. PUBVET, Londrina, V. 5, N. 23, Ed. 170, Art. 1145, 2011.

RODRIGUES FILHO et al. (2006) encontraram diferença significativa na percentagem de MS, PB, FDN e FDA entre quatro híbridos de sorgo cortados no estádio de grão pastoso, conforme Tabela 5.

TABELA 5. Composição bromatológica em percentagem de matéria seca, determinados nos híbridos avaliados

\begin{tabular}{ccccc}
\hline \multirow{2}{*}{ Híbridos } & \multicolumn{4}{c}{ Parâmetros (\%) } \\
\cline { 2 - 5 } & MS & PB & FDN & FDA \\
\hline BRS 610 & $22,86 \mathrm{c}^{*}$ & $6,97 \mathrm{~b}$ & $50,28 \mathrm{ab}$ & $41,48 \mathrm{a}$ \\
CMSXS 762 & $27,71 \mathrm{~b}$ & $7,78 \mathrm{a}$ & $48,45 \mathrm{~b}$ & $40,06 \mathrm{a}$ \\
BR 506 & $24,82 \mathrm{c}$ & $4,85 \mathrm{c}$ & $37,29 \mathrm{c}$ & $38,75 \mathrm{a}$ \\
BR 700 & $31,51 \mathrm{a}$ & $7,34 \mathrm{ab}$ & $53,05 \mathrm{a}$ & $33,82 \mathrm{~b}$ \\
\hline
\end{tabular}

* Médias seguidas de mesma letra minúscula nas colunas não diferem estatisticamente pelo teste de Tukey a $5 \%$.

FONTE: Adaptado de RODRIGUES FILHO et al. (2006)

Na Tabela 6 são apresentados os teores de digestibilidade in vitro da matéria seca (DIVMS). Todos os híbridos mostraram valores variados de digestibilidade total com teores mais elevados no estádio de grão leitoso. Todos os híbridos demostraram DIVMS mais altos nas folhas no estádio de grão leitoso e farináceo. Quanto a DIVMS do colmo, todos os híbridos apresentam maior disgestibilidade no estádio de grão leitoso e reduzem gradativamente com o avanço da maturação das plantas, isto é reflexo da ação fibrosa dos colmos desses híbridos à medida que aumenta o grau de maturação. Na panícula todos os híbridos demonstraram maiores teores de DIVMS no estádio de grão farináceo. O hibrido BR 700 não apresentou diferença significativa dos teores de DIVMS nos estádios de maturação avaliados (MACHADO, 2009). Resultados de MACHADO \& ASSIS (2010) encontraram valores de DIVMS que variaram de 60,9 a 67,9\% em folhas de sorgo cortado no estádio de grãos leitosos. 
BUSO, W.H.D. et al. Utilização do sorgo forrageiro na alimentação animal. PUBVET, Londrina, V. 5, N. 23, Ed. 170, Art. 1145, 2011.

TABELA 6. Teores de digestibilidade in vitro da matéria seca (DIVMS) de planta inteira, folhas, colmos e panículas de híbridos de sorgo em três estádios de maturação (\%)

\begin{tabular}{cccc}
\hline \multicolumn{4}{c}{ DIVMS total } \\
\hline \multirow{2}{*}{ Híbrido } & \multicolumn{3}{c}{ Estádios de maturação } \\
\cline { 2 - 4 } & Leitoso & Pastoso & Farináceo \\
\hline BRS 610 & $55,43 \mathrm{Aa} *$ & $56,13 \mathrm{Aa}$ & $54,12 \mathrm{Aa}$ \\
BR 700 & $55,90 \mathrm{Aa}$ & $52,75 \mathrm{Bb}$ & $53,60 \mathrm{Ab}$ \\
BRS 655 & $55,92 \mathrm{Aa}$ & $54,04 \mathrm{ABab}$ & $53,04 \mathrm{Ab}$ \\
\hline \multicolumn{4}{c}{ DIVMS das Folhas } \\
\hline Híbrido & \multicolumn{3}{c}{ Estádios de maturação } \\
& Leitoso & Pastoso & Farináceo \\
\hline BRS 610 & $56,80 \mathrm{Aa}$ & $50,10 \mathrm{Bb}$ & $50,39 \mathrm{Ab}$ \\
BR 700 & $50,77 \mathrm{Ba}$ & $45,15 \mathrm{Ca}$ & $47,62 \mathrm{Aa}$ \\
BRS 655 & $56,88 \mathrm{Aa}$ & $54,99 \mathrm{Aa}$ & $52,23 \mathrm{Aa}$ \\
\hline DIVMS do Colmo \\
\hline Híbrido & \multicolumn{3}{c}{ Estádios de maturação } \\
\cline { 2 - 4 } & Leitoso & Pastoso \\
\hline BRS 610 & $55,00 \mathrm{Aa}$ & $51,30 \mathrm{Ab}$ & Farináceo \\
BR 700 & $54,34 \mathrm{Aa}$ & $46,77 \mathrm{Bb}$ & $43,89 \mathrm{Ab}$ \\
BRS 655 & $52,71 \mathrm{Aa}$ & $50,62 \mathrm{Aa}$ & $46,77 \mathrm{Ab}$ \\
\hline
\end{tabular}

DIVMS das panículas

\begin{tabular}{cccc}
\hline \multirow{2}{*}{ Híbrido } & \multicolumn{3}{c}{ Estádios de maturação } \\
\cline { 2 - 4 } & Leitoso & Pastoso & Farináceo \\
\hline BRS 610 & $58,88 \mathrm{Bb}$ & $67,73 \mathrm{Aa}$ & $69,50 \mathrm{Aa}$ \\
BR 700 & $62,85 \mathrm{Aa}$ & $65,13 \mathrm{Ba}$ & $65,08 \mathrm{Ba}$ \\
BRS 655 & $54,49 \mathrm{Cc}$ & $59,76 \mathrm{Cb}$ & $62,32 \mathrm{Ca}$ \\
\hline
\end{tabular}

* Médias seguidas de mesma letra maiúsculas nas colunas e minúscula na linha não diferem estatisticamente pelo teste de SNK a 5\%.

FONTE: Adaptado de MACHADO (2009) 
BUSO, W.H.D. et al. Utilização do sorgo forrageiro na alimentação animal. PUBVET, Londrina, V. 5, N. 23, Ed. 170, Art. 1145, 2011.

\section{Utilização do sorgo para pastejo}

A utilização de pastagens tropicais tem sido apontada como uma das alternativas de menor custo/benefício para a terminação de animais exclusivamente a pasto, principalmente quando os valores nutricionais das espécies forrageiras são bons o bastante para minimizar os custos com suplementações. A utilização de pastagem de sorgo para a alimentação de animais em terminação pode ser uma alternativa recomendada aos produtores, principalmente por ser uma espécie de crescimento rápido e resistente a períodos de escassez de água (OSMARI, 2010).

De acordo com SOLLENBERGER et al. (2005) o controle da massa de forragem em pastejo deve ser realizado em função de suas porções foliares, visto que é o componente do manejo que permite predizer com segurança o desempenho animal, por integrar a massa de lâminas foliares com a taxa de lotação.

Os teores de proteína bruta (PB) decresceram de forma linear à medida que aumentaram as ofertas de lâminas foliares conforme Figura 1, pois quanto maior a massa de forragem, maiores as perdas por senescência em consequência de sua baixa utilização, que favorece a perda de qualidade da pastagem (OSMARI, 2010).

NEUMANN et al. (2005) observaram diferença significativa para os teores de PB e Digestiblidade in vitro da Matéria Orgânica (DIVMO) da planta inteira em pastagem de sorgo. Ocorreu decréscimo acentuado de PB com o avanço do estádio de desenvolvimento das plantas com valores de 9,9\% em dezembro, $7,5 \%$ em janeiro e 7,2\% em fevereiro. O mesmo comportamento foi observado para DIVMO com valores de $50,4 \%, 43,0 \%$ e $38,8 \%$ para os mesmos períodos, respectivamente. Esses fatores ocorreram em função da maturidade fisiológica das plantas conforme avançou a utilização da pastagem. No primeiro período de avaliação foram encontrados menores teores de MS e maiores de PB e DIVMO, justificados pela participação de $50,2 \%$ de folhas e $42,6 \%$ de colmos. Isto explica a redução da PB e DIVMO à medida que o período de utilização da pastagem avança. 
BUSO, W.H.D. et al. Utilização do sorgo forrageiro na alimentação animal. PUBVET, Londrina, V. 5, N. 23, Ed. 170, Art. 1145, 2011.

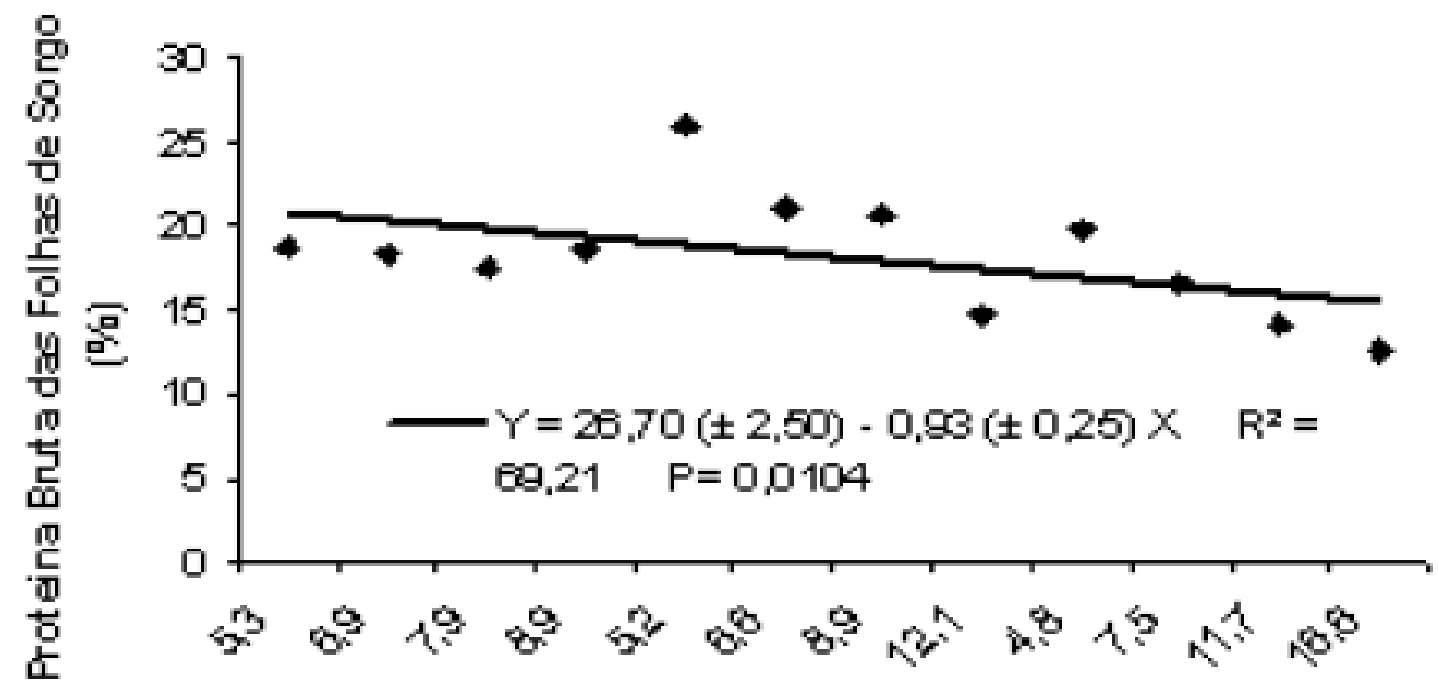

Cferta de Forragem Real

FIGURA 1 - Proteína bruta presente nas folhas de sorgo manejados sob diferentes ofertas de lâminas foliares (OSMARI, 2010)

Segundo SIMILI et al. (2008) pastagem de sorgo adubada com três níveis de nitrogênio $\left(100,200\right.$ e $300 \mathrm{~kg} \mathrm{~N} \mathrm{ha}^{-1}$ ) não influenciou a produção de massa seca da forragem com valores de $17,4 \%, 16,3 \%$ e $17,3 \%$, respectivamente. Mas encontraram resposta significativa para PB (15,1\%, $16,4 \%, 15,7 \%), \operatorname{FDN}(65,3 \%, 65,8 \%$ e $64,5 \%)$ e FDA $(35,5 \%, 37,8 \%$ e $39,6 \%)$, respectivamente. Estes teores permitiram recomendar a dosagem de $100 \mathrm{~kg} \mathrm{ha}^{-1}$ de $\mathrm{N}$ ser suficiente para o desenvolvimento do sorgo nas condições em que o trabalho foi desenvolvido. A fertilidade do solo onde foi conduzido o trabalho apresentava níveis altos, assim não ocorreu resposta à adubação nitrogenada.

Os diferentes níveis de adubação nitrogenada não influenciaram na produção de massa seca, inicial e residual, antes e após o pastejo dos animais, das plantas inteiras (Tabela 7). Provocaram redução da porcentagem de folhas e elevação da porcentagem de colmos do híbrido AG 2501C (SIMILI et al., 2010). 
BUSO, W.H.D. et al. Utilização do sorgo forrageiro na alimentação animal. PUBVET, Londrina, V. 5, N. 23, Ed. 170, Art. 1145, 2011.

GONTIJO et al. (2008) avaliaram seis híbridos de sorgo com capimsudão em duas épocas de plantio e três cortes sucessivos e observaram valores médios de 57,0\% para DIVMS, $16,3 \%$ para PB, 54,8\% para FDN e $31,0 \%$ para FDA.

TABELA 7. Massas seca de forragem inicial e residual, porcentagens de colmo e folha do híbrido de sorgo-sudão submetidos às adubações nitrogenada

\begin{tabular}{lccc}
\hline \multirow{2}{*}{ Variável } & \multicolumn{3}{c}{ Doses de N $\left(\mathrm{kg} \mathrm{ha}^{-1}\right)$} \\
\cline { 2 - 4 } & 100 & 200 & 300 \\
\hline Massa seca inicial $\left(\mathrm{kg} \mathrm{ha}^{-1}\right.$ de MS) & 2713 & 2680 & 3009 \\
Massa seca residual ( $\mathrm{kg} \mathrm{ha}^{-1}$ de MS) & 949 & 943 & 1001 \\
Colmo (\%) & $49,9 \mathrm{~b} *$ & $52,4 \mathrm{ab}$ & $54,4 \mathrm{a}$ \\
Folha (\%) & $41,2 \mathrm{a}$ & $37,7 \mathrm{ab}$ & $35,7 \mathrm{~b}$ \\
\hline
\end{tabular}

* Médias seguidas de mesma letra minúscula na linha não diferem estatisticamente pelo teste de Tukey a $5 \%$.

FONTE: Adaptado de SIMILI et al. (2010)

\section{Utilização do sorgo para silagem}

A silagem é resultante da fermentação anaeróbica de plantas forrageiras, pela ação de bactérias, que convertem açúcares em ácidos orgânicos possuindo quantidades adequadas de massa seca. A fermentação provoca alterações na composição das frações nitrogenadas, reduz os teores de proteína e aumenta os aminoácidos livres (OSHIMA \& McDONALD, 1978). É um processo muito importante para conservação de plantas forrageiras para servir de alimento, durante os períodos de escassez de forragens em todo o mundo. No Brasil, o uso da silagem é realizado em razão da produção irregular das plantas forrageiras durante a estação mais seca do ano.

MACHADO (2009) observou que à medida que o estádio de maturação das plantas avançou e a umidade reduziu, ocorreu aumento no acúmulo de matéria seca em híbridos de sorgo, assim existiu diferença 
BUSO, W.H.D. et al. Utilização do sorgo forrageiro na alimentação animal. PUBVET, Londrina, V. 5, N. 23, Ed. 170, Art. 1145, 2011.

significativa entre os diferentes estádios de corte das plantas (Tabela 8). Os teores de proteína bruta apresentaram pequenas variações entre os vários estádios de maturação das plantas decrescendo conforme avançou a maturação. Os diferentes híbridos não apresentaram diferença significativa no estádio leitoso e farináceo. ARAújo et al. (2007), CHIESA et al. (2008) e MACHADO (2010), encontraram resultados semelhantes.

TABELA 8. Teores de matéria seca e proteína bruta da silagem de híbridos de sorgo em três estádios de maturação

\begin{tabular}{cccc}
\hline \multicolumn{4}{c}{ Matéria seca (\%) } \\
\hline \multirow{2}{*}{ Híbrido } & \multicolumn{3}{c}{ Estádios de maturação } \\
\cline { 2 - 4 } & Leitoso & Pastoso & Farináceo \\
\hline BRS 610 & $22,86 \mathrm{Cc} *$ & $27,34 \mathrm{Bb}$ & $29,52 \mathrm{Ba}$ \\
BR 700 & $28,06 \mathrm{Ac}$ & $38,66 \mathrm{Ab}$ & $41,27 \mathrm{Aa}$ \\
BRS 655 & $25,67 \mathrm{Bb}$ & $25,54 \mathrm{Cb}$ & $30,29 \mathrm{Ba}$ \\
\hline \multicolumn{4}{c}{ Proteína bruta (\%) } \\
\hline \multirow{4}{*}{ Estádios de maturação } \\
\hline BRS 610 & Leitoso & Pastoso & Farináceo \\
BR 700 & $6,15 \mathrm{Aa}$ & $6,13 \mathrm{Aba}$ & $5,71 \mathrm{Aa}$ \\
BRS 655 & $6,49 \mathrm{Aa}$ & $5,81 \mathrm{Bb}$ & $5,96 \mathrm{Aab}$ \\
& $6,81 \mathrm{Aa}$ & $6,66 \mathrm{Aa}$ & $6,10 \mathrm{Ab}$
\end{tabular}

* Médias seguidas de mesma letra maiúsculas, nas colunas, e minúscula, na linha, não diferem estatisticamente pelo teste de SNK a 5\%

FONTE: Adaptado de MACHADO (2009)

Os teores de FDN e FDA na silagem de híbridos de sorgo apresentaram decréscimo significativo à medida que os estádios de maturação avançaram, possivelmente pela maior participação da panícula e grãos, redução na quantidade de folhas e colmos no material ensilado. A DIVMS apresentou comportamento variado com o avanço dos estádios de maturação, essa variação ocorre pelas variações nas proporções das partes da planta e 
BUSO, W.H.D. et al. Utilização do sorgo forrageiro na alimentação animal. PUBVET, Londrina, V. 5, N. 23, Ed. 170, Art. 1145, 2011.

pelas diferenças nos valores nutricionais dessas frações, o que interfere na qualidade final da silagem, conforme demonstrado na Tabela 9 (PIRES et al., 2006; ARAÚJO et al., 2007; MACHADO, 2009; MACHADO, 2010).

TABELA 9. Teores de Fibra em Detergente Neutro (FDN), Fibra em Detergente Ácido (FDA) e Digestibilidade da Matéria Seca (DIVMS) da silagem de híbridos de sorgo em três estádios de maturação

\begin{tabular}{cccc}
\hline \multicolumn{4}{c}{ FDN (\%) } \\
\hline \multirow{2}{*}{ Híbrido } & \multicolumn{3}{c}{ Estádios de maturação } \\
\cline { 2 - 4 } & Leitoso & Pastoso & Farináceo \\
\hline BRS 610 & $59,32 \mathrm{Aa} *$ & $54,94 \mathrm{ABb}$ & $54,89 \mathrm{Ab}$ \\
BR 700 & $59,69 \mathrm{Aa}$ & $57,26 \mathrm{Aab}$ & $55,80 \mathrm{Ab}$ \\
BRS 655 & $58,37 \mathrm{Aa}$ & $52,85 \mathrm{Bb}$ & $52,85 \mathrm{Ab}$ \\
\hline \multicolumn{4}{c}{ FDA (\%) } \\
\hline Híbrido & Estádios de maturação \\
\cline { 2 - 4 } & Leitoso & Pastoso & Farináceo \\
\hline BRS 610 & $34,45 \mathrm{Aa}$ & $34,44 \mathrm{Ab}$ & $35,15 \mathrm{Ab}$ \\
BR 700 & $37,34 \mathrm{Aa}$ & $35,55 \mathrm{Aa}$ & $32,89 \mathrm{Ab}$ \\
BRS 655 & $36,87 \mathrm{Aa}$ & $33,72 \mathrm{Ab}$ & $32,91 \mathrm{Ab}$ \\
\hline & \multicolumn{3}{c}{ DIVMS (\%) } \\
\hline Híbrido & Estádios de maturação \\
\hline BRS 610 & $50,73 \mathrm{Cb}$ & $54,50 \mathrm{Aa}$ & $55,55 \mathrm{Aa}$ \\
BR 700 & $53,38 \mathrm{Ba}$ & $51,69 \mathrm{Ba}$ & $53,02 \mathrm{Ba}$ \\
BRS 655 & $55,32 \mathrm{Aa}$ & $53,90 \mathrm{Aab}$ & $52,11 \mathrm{Bb}$ \\
\hline
\end{tabular}

* Médias seguidas de mesma letra maiúsculas nas colunas e minúscula na linha não diferem estatisticamente pelo teste de SNK a 5\%.

FONTE: Adaptado de MACHADO (2010)

No trabalho de MACHADO (2010), os teores de MS da silagem variaram de 22,31 a $38,06 \%$. A MS variou conforme avançou os estádios de 
BUSO, W.H.D. et al. Utilização do sorgo forrageiro na alimentação animal. PUBVET, Londrina, V. 5, N. 23, Ed. 170, Art. 1145, 2011.

maturação das plantas. Cultivares com menor teor de umidade do colmo, desidratação mais intensa das folhas e maior proporção de panícula e menor de colmo na planta contribui para maiores teores de MS. Resultados semelhantes foram obtidos por SOUZA et al. (2003) e TOMICH et al. (2006).

A composição bromatológica do sorgo antes da ensilagem, da silagem pura e misturada com concentrado fornecido aos animais esta na Tabela 10. 0 sorgo foi ensilado no estádio de grão farináceo. Os teores de MS aumentaram significativamente com a adição de concentrado mesmo fato ocorreu com a PB da silagem. Já os teores de FDN e FDA decresceram com a adição do concentrado. $O$ aumento na quantidade de concentrado exerceu influência significativa sobre a digestibilidade da matéria seca (DMS), devido à elevação de carboidratos não-estruturais que são mais digestíveis que os estruturais, e na digestibilidade da proteína bruta (DPB) (SIMON et al., 2009).

TABELA 10. Composição bromatológica de planta inteira e da silagem de sorgo com e sem adição de concentrado e digestibilidade da matéria seca e proteína bruta

\begin{tabular}{cccccc}
\hline \multirow{2}{*}{ Variável } & Planta & \multicolumn{4}{c}{ Nível de concentrado na silagem de sorgo } \\
\cline { 2 - 6 } & inteira & $0 \%$ & $15 \%$ & $30 \%$ & $45 \%$ \\
\hline MS (\%) & 32,40 & $34,76 \mathrm{~d} *$ & $38,79 \mathrm{c}$ & $43,18 \mathrm{~b}$ & $45,10 \mathrm{a}$ \\
PB (\%) & 8,03 & $7,61 \mathrm{~d}$ & $9,20 \mathrm{c}$ & $14,63 \mathrm{~b}$ & $20,12 \mathrm{a}$ \\
FDN (\%) & 67,02 & $66,30 \mathrm{a}$ & $53,31 \mathrm{~b}$ & $48,74 \mathrm{c}$ & $45,39 \mathrm{~d}$ \\
FDA (\%) & 42,10 & $40,14 \mathrm{a}$ & $31,96 \mathrm{~b}$ & $29,12 \mathrm{c}$ & $24,63 \mathrm{~d}$ \\
DMS (\%) & - & $48,32 \mathrm{~d}$ & $61,96 \mathrm{c}$ & $68,12 \mathrm{~b}$ & $69,77 \mathrm{a}$ \\
DPB (\%) & - & $37,41 \mathrm{~d}$ & $44,62 \mathrm{c}$ & $74,12 \mathrm{~b}$ & $83,50 \mathrm{a}$ \\
\hline
\end{tabular}

* Médias seguidas de mesma letra minúsculas nas linhas não diferem estatisticamente pelo teste de Duncan a $5 \%$.

FONTE: Adaptado de SIMON et al. (2009)

SOUZA et al. (2003) encontraram teores de PB entre 5,7 a 6,8\% na silagem de sorgo confeccionada no estádio de grão farináceo. Estas variações 
BUSO, W.H.D. et al. Utilização do sorgo forrageiro na alimentação animal. PUBVET, Londrina, V. 5, N. 23, Ed. 170, Art. 1145, 2011.

ocorreram devido a maior participação de folhas em cultivares de sorgo de porte baixo, enquanto cultivares de porte alto possui maior quantidade de colmo o que leva a redução no teor de proteína. Os teores de FDN variaram de 60,1 a $65 \%$, valores que estão dentro da faixa ideal para silagem de sorgo. PEREIRA et al. (2006) chegaram a resultados próximos.

PIRES et al. (2006) observaram que os teores de PB decresceram significativamente com o avanço do estádio de maturação, conforme apresentado na Tabela 11. Esta redução deve-se ao decréscimo dos níveis de PB na folha e colmo pela mobilização de nitrogênio para a formação da panícula.

TABELA 11. Teores de matéria seca e proteína bruta da silagem de híbridos de sorgo em três estádios de maturação

\begin{tabular}{cccc}
\hline \multicolumn{4}{c}{ Matéria seca (\%) } \\
\hline \multirow{2}{*}{ Híbrido } & \multicolumn{3}{c}{ Estádios de maturação } \\
\cline { 2 - 4 } & Leitoso & Pastoso & Farináceo \\
\hline AG 2006 & $23,93 \mathrm{Ca} *$ & $33,33 \mathrm{Ba}$ & $38,82 \mathrm{Aa}$ \\
BR 700 & $25,31 \mathrm{Ca}$ & $32,52 \mathrm{Ba}$ & $39,74 \mathrm{Aa}$ \\
BRS 601 & $21,92 \mathrm{Aa}$ & $28,80 \mathrm{Aa}$ & $29,46 \mathrm{Aa}$ \\
\hline \multicolumn{4}{c}{ Proteína bruta (\%) } \\
\hline \multirow{4}{*}{ Híbrido } & Estádios de maturação \\
\cline { 2 - 4 } & Leitoso & Pastoso & Farináceo \\
\hline AG 2006 & $8,18 \mathrm{Aa}$ & $7,46 \mathrm{Aa}$ & $6,31 \mathrm{Ca}$ \\
BR 700 & $7,32 \mathrm{Aa}$ & $7,07 \mathrm{Aa}$ & $6,66 \mathrm{Ca}$ \\
BRS 601 & $6,39 \mathrm{Ab}$ & $5,92 \mathrm{Ab}$ & $6,17 \mathrm{Aa}$
\end{tabular}

* Médias seguidas de mesma letra minúsculas nas colunas e maiúscula na linha não diferem estatisticamente pelo teste de SNK a 5\%.

FONTE: Adaptado de PIRES et al. (2009)

Na Tabela 12 verifica-se que a fração solúvel "a" da matéria seca e PB da silagem de milho foi acima da silagem de sorgo e de Brachiaria 
BUSO, W.H.D. et al. Utilização do sorgo forrageiro na alimentação animal. PUBVET, Londrina, V. 5, N. 23, Ed. 170, Art. 1145, 2011.

brizantha. Isto ocorreu possivelmente pela silagem de milho apresentar maior teor de açúcar residual. A fração insolúvel potencialmente degradável " $B$ " da silagem de milho apresentou valores abaixo das demais silagens (PIRES et al. 2010).

TABELA 12. Parâmetros de degradação ruminal da matéria seca (MS), proteína bruta (PB), fibra em detergente neutro (FDN) e fibra em detergente ácido (FDA) das silagens de milho, sorgo e Brachiaria incubadas no rúmen

\begin{tabular}{|c|c|c|c|c|}
\hline \multirow{3}{*}{ Silagem } & \multicolumn{4}{|c|}{ Parâmetro } \\
\hline & $a(\%)$ & $\mathrm{B}(\%)$ & $\mathrm{I}(\%)$ & $c(/ h)$ \\
\hline & \multicolumn{4}{|c|}{ MS } \\
\hline Milho & 38,5 & 43,6 & 17,9 & 0,036 \\
\hline Sorgo & 21,4 & 52,5 & 26,1 & 0,042 \\
\hline \multirow{2}{*}{ Brachiaria } & 12,5 & 48,3 & 39,2 & 0,039 \\
\hline & \multicolumn{4}{|c|}{ PB } \\
\hline Milho & 38,4 & 48,6 & 13,0 & 0,040 \\
\hline Sorgo & 30,3 & 51,5 & 18,2 & 0,049 \\
\hline \multirow[t]{2}{*}{ Brachiaria } & 23,7 & 51,5 & 24,8 & 0,044 \\
\hline & \multicolumn{4}{|c|}{ FDN } \\
\hline Milho & - & 71,9 & 28,1 & 0,051 \\
\hline Sorgo & - & 66,6 & 33,4 & 0,047 \\
\hline \multirow[t]{2}{*}{ Brachiaria } & - & 57,6 & 42,5 & 0,036 \\
\hline & \multicolumn{4}{|c|}{ FDA } \\
\hline Milho & - & 61,5 & 38,5 & 0,038 \\
\hline Sorgo & - & 49,7 & 50,3 & 0,024 \\
\hline Brachiaria & - & 48,6 & 51,4 & 0,035 \\
\hline
\end{tabular}

$\mathrm{a}=$ fração solúvel; $\mathrm{B} / \mathrm{B}_{\mathrm{p}}=$ fração insolúvel potencialmente degradável; $\mathrm{I} / \mathrm{I}_{\mathrm{p}}=$ fração indegradável; $c=$ taxa de degradação da fração $B$.

FONTE: Adaptado de PIRES et al. (2010) 
BUSO, W.H.D. et al. Utilização do sorgo forrageiro na alimentação animal. PUBVET, Londrina, V. 5, N. 23, Ed. 170, Art. 1145, 2011.

No trabalho de OLIVEIRA et al. (2009) verificaram que a matéria seca da silagem aumentou significativamente em função da dose de nitrogênio aplicada. Os teores variaram de 24,0 a $28,7 \%$. Os de PB, FDN e FDA não diferiram em função dos níveis de nitrogênio com teores entre 6,4 a 7,5\%; 58,9 a $59,5 \%$ e 32,9 a $33,7 \%$, respectivamente, com ensilagem realizada no estádio de grão pastoso.

A panícula é um componente que influencia positivamente na qualidade da silagem, assim quanto maior a porcentagem de panícula na estrutura da planta melhor o valor nutricional da silagem. Nem sempre os materiais com maior potencial produtivo produzirá forragem com alto valor nutricional. Mesmo assim, não verificou diferenças significativas para a DIVMO quando compararam híbridos com diferentes concentrações de panícula (NEUMANN, et al. (2002).

NEUMANN, et al. (2005) observaram que o teor de PB no material de origem e na silagem não apresentaram diferença significativa com valores de 4,55 e $4,83 \%$, respectivamente.

Segundo PIRES et al. (2010) a silagem de milho demonstrou maior potencial de degradação de MS e de PB, possivelmente por não apresentar fatores antinutricionais como presença de tanino (Figura 2). Quanto aos parâmetros de degradação ruminal da FDN e FDA observaram maiores valores para a silagem de milho, seguidos pelos de sorgo e de brachiaria (Figura 3). A silagem de sorgo e de brachiaria apresentaram perfil de degradabilidade de FDA semelhantes em todos os períodos de incubação (Figura 3) e a silagem de milho destacou-se pelos resultados mais altos.

Segundo İTAVO et al. (2009) o uso de silagem de grão úmidos de milho pode ser substituído pelo de sorgo sem prejuízos ao desempenho dos animais, pois não encontraram diferenças na digestibilidade da matéria seca das diferentes silagens. 
BUSO, W.H.D. et al. Utilização do sorgo forrageiro na alimentação animal. PUBVET, Londrina, V. 5, N. 23, Ed. 170, Art. 1145, 2011.

$\rightarrow$ Sil milho $\rightarrow$ Sil sorgo $\triangle$ Sil braquiária
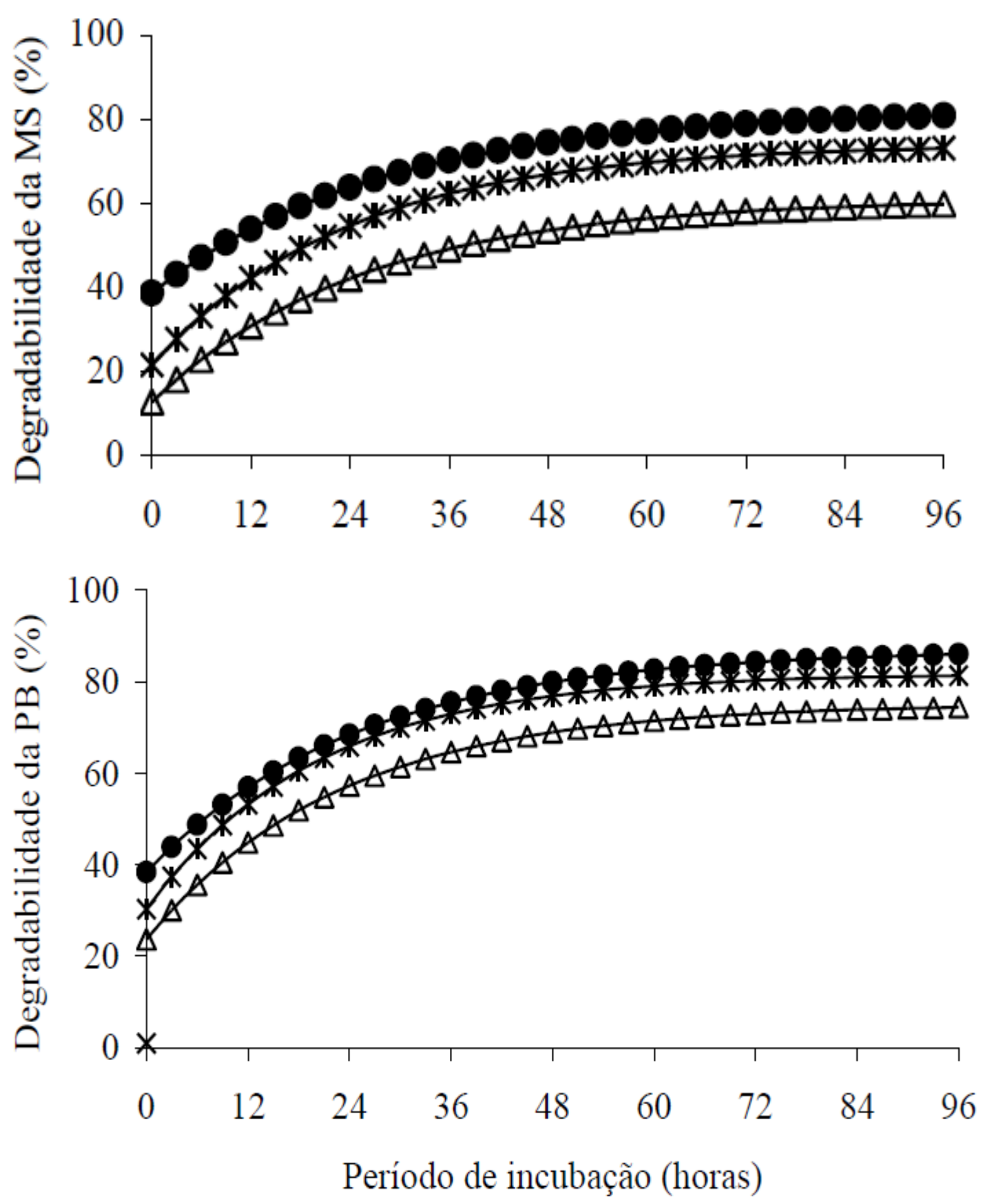

FIGURA 2 - Degradabilidade da matéria seca (MS) e proteína bruta (PB) de silagens de milho, de sorgo e de Brachiaria em função do período de incubação(horas) (PIRES et al., 2010) 
BUSO, W.H.D. et al. Utilização do sorgo forrageiro na alimentação animal. PUBVET, Londrina, V. 5, N. 23, Ed. 170, Art. 1145, 2011.

$\rightarrow$ Sil milho $\rightarrow$ Sil sorgo $\triangle$ Sil braquiária
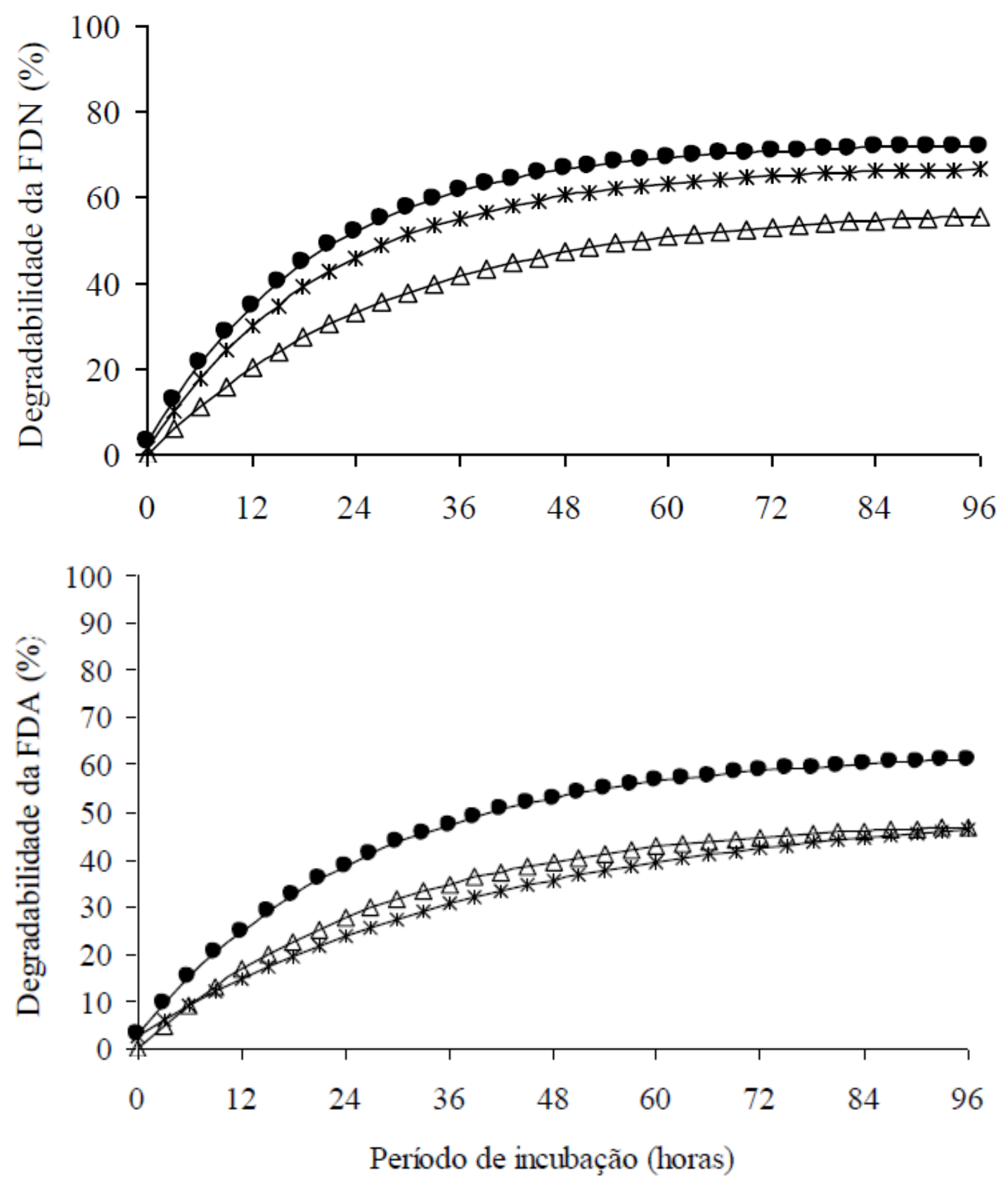

FIGURA 3 - Degradabilidade da fibra em detergente neutro (FDN) e da fibra em detergente ácido (FDA) de silagens de milho, de sorgo e de Brachiaria em função do período de incubação(horas) (PIRES et al., 2010) 
BUSO, W.H.D. et al. Utilização do sorgo forrageiro na alimentação animal. PUBVET, Londrina, V. 5, N. 23, Ed. 170, Art. 1145, 2011.

\section{CONSIDERAÇÕES FINAIS}

- O sorgo pode ser utilizado para pastejo e silagem, pois possui potencial produtivo elevado, disponibilidade de matéria seca e valor nutritivo.

- A silagem de milho pode ser substituída pela de sorgo sem perdas na produtividade dos animais.

\section{REFERÊNCIAS}

ARAÚJO, V.L.; RODRIGUEZ, N.M.; GONÇALVES, L.C.; RODRIGUES, J.A.S.; BORGES, I.; BORGES, A.L.C.C.; SALIBA, E.O.S. Qualidade das silagens de três híbridos ensilados em cinco diferentes estádios de maturação. Arquivos Brasileiro Medicina Veterinária e Zootecnia, Belo Horizonte, v. 59, n.1, p.168-174, 2007.

BARRIÈRE, Y.; RALPH, J.; MÉCHIN, V.; GUILLAUMIE, S.; GRABBER, J. H.; ARGILLIER, O.; CHABBERT, B.; LAPIERRE, C. Genetic and molecular basis of grass cell wall biosynthesis and degradability. II. Lessons from brown-midrib mutants. Comptes Rendus Biologies, Paris, v.327, p.847-860, 2004.

CASLER, M. D.; PEDERSEN, J. F.; UNDERSANDER, D. J. Forage yield and economic losses associated with the brown-midrib trait in sudangrass. Crop Science, Madison, v.43, p.782789, 2003.

COELHO, A.M. Cultivares de sorgo para Minas Gerais. Informe Agropecuário, Belo Horizonte, v.5, n.56, p.22-26, 1979.

EVANGELISTA, A.R.; ABREU, J.G.; AMARAL, P.N.C.; PEREIRA, R.C.; SALVADOR, F.M.; LOPES, J.; SOARES, L.Q. Composição bromatológica de silagens de sorgo (Sorghum bicolor (L.) MOENCH) aditivadas com forragem de leucena (Leucaena leucocephala (LAM.) DEWIT). Ciência agrotecnologia, Lavras, v.29, n.2, p.429-435, 2005.

FRITZ, J. O.; MOORE, K. J.; JASTER, E. H. Digestion kinetics and cell wall composition of brown midrib sorghum $x$ sudangrass morphological components. Crop Science, Madison, v.30, p.213-219, 1988.

GONTIJO, M.H.R.; BORGES, A.L.C.C.; GONÇALVES, L.C.; RODRIGUES, J.A.S.; GOMES, S.P.; BORGES, I.; RODRIGUEZ, N.M.; CAMPOS, M.M.; PANCOTI, C.G. Qualidade nutricional de seis híbridos de sorgo com capim-sudão submetidos a épocas de plantio e cortes distintas. Revista Brasileira de Milho e Sorgo, Sete Lagoas, v.7, n.1, p.45-56, 2008.

ÍTAVO, C.C.B.F.; MORAIS, M.G.; ÍTAVO, L.C.V.; SOUZA, A.R.D.L.; DAVY, F.C.A.; BIBERG, F.A.; ALVES, W.B.; SANTOS, M.V. Consumo e disgestibilidade de nutrientes de dietas com silagens de grãos úmidos de milho ou sorgo, em ovino. Arquivos Brasileiro de Medicina Veterinária Zootecnia, Belo Horizonte, v. 61, n.2, p.452-459, 2009.

JASMAN, A.J.M. Tannins in feedstuffs for simple stomache animals. Nutrition Research Reviews, Cambridge, v.6, p. 209-236, 1993. 
MACHADO, F.S. Digestibilidade, partição de energia e produção de metano em ovinos alimentados com silagens de híbridos de sorgo em diferentes estádios de maturação. 2010. 107 f. Tese (Doutorado em zootecnia). Universidade Federal de Minas Gerais, Escola de Veterinária, Belo Horizonte.

MACHADO, F.S. Avaliação agronômica e nutricional de três híbridos de sorgo [Sorghum bicolor (L.) Moench] e de suas silagens em três estádios de maturação. 2009. 109 f. Dissertação (Mestrado em zootecnia). Universidade Federal de Minas Gerais, Escola de Veterinária, Belo Horizonte.

MACHADO, L.A.Z.; ASSIS, P.G.G. Produção de palha e forragem por espécies anuais e perenes em sucessão à soja. Pesquisa agropecuária brasileira, Brasília, v.45, n.4, p.415-422, 2010.

MAGALHÃES, P.C.; RODRIGUES, W.A.; DURÃES, F.O.M. Tanino no grão de sorgo: bases fisiológicas e métodos de determinação. Sete Lagoas: EMBRAPA, CNPMS, 1997. 26P.

MAGALHÃES, P.C.; DURÃES, F.O.M.; RODRIGUES, J.A.S. Fisiologia da planta de sorgo. Sete Lagoas: Ministério da Agricultura, Pecuária e Abastecimento. 2003. 4p.

MOLINA, L.R.; RODRIGUEZ, N.M.; SOUSA, B.M.; GONÇALVES, L.C.; BORGES, I. Parâmetros de degradabilidade potencial da matéria seca e da proteína bruta das silagens de seis genótipos de sorgo (Sorghum bicolor (L.) Moench), com e sem tanino no grão, avaliados pela técnica in situ. Revista Brasileira de Zootecnia, Viçosa, v.32, n.1, p.222-228, 2003.

MONTAGNER, D.B.; ROCHA, M.G.; NORNBERG, J.L.; CHIELL, Z. G.; MONDADORI, R.G.; ESTIVALET, R.C.; CALEGARI, C. Características agronômicas e bromatológicas de cultivares avaliados no ensaio sul-rio-grandese de sorgo forrageiro. Revista Brasileira Agrociência, Pelotas, v.11, n.4, p.447-452, 2005.

NEUMANN, M.; RESTLE, J.; ALVES FILHO, D.C.; BRONDANI, I.L.; PELLEGRINI, L.G.; FREITAS, A.K. Avaliação do valor nutritivo da planta e da silagem de diferentes híbridos de sorgo (Sorghum bicolor, L. Moench). Revista Brasileira de Zootecnia, Viçosa, v.31, n.1, p.293301, 2002. (Suplemento)

NEUMANN, M.; RESTLE, J.; BRONDANI, I.L.; NORNBERG, J.L.; MELLO, R.O.; SOUZA, A.N.M.; PELLEGRINI, L.G. Efeito do tamanho da partícula e do tipo de silo sobre o valor nutritivo da silagem de sorgo (Sorghum bicolor, L. Moench). Revista Brasileira de Milho e Sorgo, Sete Lagoas, v.4, n.2, p.224-242, 2005.

NEUMANN, M.; RESTLE, J.; FILHO, D.C.A.; MACCARI, M.; PELLEGRINI, L.G.; SOUZA, A.N.M.; PEIXOTO, L.A.O. Produção de forragem e custo de produção da pastejo contínuo. Revista Brasileira de Agrociência, Pelotas, v.11, n.2, p.215-220, 2005.

OLIVEIRA, P.R.; FRANÇA, A.F.S.; SILVA, A.G.; MIYAGI, E.S.; OLIVEIRA, E.R.; PERÓN, H,J.M.C. Composição bromatológica e quatro híbridos de sorgo forrageiro sob doses de nitrogênio. Ciência Animal Brasileira, Goiânia, v.10, n.4, p.1003-1012, 2009.

OSHIMA, M.; McDONALD, P. A review of changes in nitrogenous compounds in herbages during ensiling. Journal Science Food Agriculture, London, v.29, p.497-505, 1978.

OSMARI, M.P. Dinânica da pastagem de sorgo em diferentes ofertas de lâminas foliares na terminação de vacas de descarte. 2010. 117 f. Dissertação (Mestrado em zootecnia). Universidade Federal de Santa Maria, Santa Maria. 
PEREIRA, D.H.; PEREIRA, O.G.; VALADARES FILHO, S.C.; GARCIA, R.; OLIVEIRA, A.P.; MARTINS, F.H.; VIANA, V. Consumo, digestibilidade dos nutrientes e desempenho de bovinos de corte recebendo silagem de sorgo (Sorghum bicolor (L.) Moench) e diferentes proporções de concentrado. Revista Brasileira Zootecnia., Viçosa, v.35, n.1, p.282-291, 2006.

PIRES, A.J.V.; REIS R.A.; CARVALHO, G.G.P.; SIQUEIRA, G.R.; BERNARDES, T.F.; RUGGIERI, A.C.; ROTH, M.T.P. Degradabilidade ruminal da matéria seca, da proteína bruta e da fração fibrosa de silagens de milho, de sorgo e de Brachiaria brizantha. Arquivos Brasileiro de Medicina Veterinária e Zootecnia, Belo Horizonte, v. 62, n.2, p.391-400, 2010.

PIRES, D.A.A.; GONÇALVES, L.C.; RODRIGUES, J.A.S.; JAYME, D.G.; GUIMARÃES JÚNIOR, R.; RODRIGUEZ, N.M.; BORGES, I.; BORGES, A.L.C.C.; JAYME, C.G.; BOTELHO, P.R.F.; LIMA, L.O.B. Degradabilidade in situ das frações fibrosas da silagem de sorgo. Revista Brasileira de Milho e Sorgo, Sete Lagoas, v.8, n.2, p.175-185, 2009.

PIRES, D.A.A.; GUIMARÃES JÚNIOR, R.; JAYME, D.G.; GONÇALVES, L.C.; RODRIGUES, J.A.S.; RODRIGUEZ, N.M.; BORGES, I.; BORGES, A.L.C.C.; JAYME, C.G. Qualidade e valor nutritivo das silagens de três híbridos de sorgo (Sorghum bicolor L.) colhidos em diferentes estádios de maturação. Revista Brasileira de Milho e Sorgo, Sete Lagoas, v.5, n.2, p.241-256, 2006.

RIBAS, M.N. Avaliação agronômica e nutricional de híbridos de sorgo com capimsudão, normais e mutantes bmr - portadores de nervura marrom. 2010. $140 \mathrm{f}$. Tese (Doutorado em zootecnia). Universidade Federal de Minas Gerais, Escola de Veterinária, Belo Horizonte.

RIBAS, P.M. Cultivo do sorgo. 2008. Disponível em: http://www.cnpms.embrapa.br/publicacoes/sorgo 4 ed/plantio-plantio.html Acesso em: 10 de agosto de 2010.

RODRIGUES FILHO, O., FRANÇA, A.F.S., OLIVEIRA, R.P., OLIVEIRA, E.R., ROSA, B.SOARES, T.V.; MELLO, S.Q.S. Produção e composição de quatro híbridos de sorgo forrageiro (Sorghum bicolor L. Moench) submetidos a três doses de nitrogênio. Ciência Animal Brasileira, Goiânia, v.7, n.1, p.37-48, 2006.

SILVA, L. M.; ALQUINI, Y.; CAVALLET, V. J. Inter-relações entre a anatomia vegetal e a produção vegetal. Acta Botânica Brasilica, São Paulo, v.19, n.1, p.183-194, 2005.

SIMILI, F.F.; GOMIDE, C.A.M.; MOREIRA, A.L.; REIS, R.A.; LIMA, M.L.P.; PAZ, C.C.P. Respostas do híbrido de sorgo-sudão às adubações nitrogenada e potássica: características estruturais e produtivas. Ciência agrotecnologia, Lavras, v.34, n.1, p.87-94, 2010.

SIMILI, F.F.; REIS, R.A.; FURLAN, B.N.; PAZ, C.C.P.; LIMA, M.L.P.; BELLINGIERI, P.A. Resposta do híbrido de sorgo-sudão à adubação nitrogenada e potássica: composição química e digestibilidade in vitro da matéria orgânica. Ciência agrotecnologia, Lavras, v.32, n.2, p.474-480, 2008.

SIMON, J.E.; LOURENÇO JUNIOR, J.B.; FERREIRA, G.D.G.; SANTOS, N.F.A.; NAHUM, B.S.; MONTEIRO, E.M.M. Consumo e digestibilidade de silagem de sorgo como alternativa para alimentação suplementar de ruminantes na amazônia oriental. Amazônia: Ciência \& Desenvolvimento, Belém, v.4, n.8, p.103-119. 2009.

SOLLENBERGER, L. E.; MOORE, J.E.; ALLEN, V.G.; PEDREIRA, C.G.S. Reporting forage allwance in grazing experiments. Crop Science, Madison, v. 45, p.896-900, 2005. 
SOUSA, D.M.G.; LOBATO, E. Calagem e adubação para culturas anuais e semiperenes. In: SOUZA, D.M.G.; LOBATO, E. Cerrado correção do solo e adubação. 2.ed. Brasília. 2004. cap. 12 , p.310-311.

SOUZA, V.G.; PEREIRA, O.G.; MORAES, S.A.; GARCIA, R.; VALADARES FILHO, S.C.; ZAGO, C.P.; FREITAS, E.V.V. Valor nutritivo de silagens de sorgo. Revista Brasileira de Zootecnia, Viçosa, v.32, n.3, p.753-759, 2003.

TOMICH, T.R.; TOMICH, R.G.P.; GONÇALVES, L.C.; BORGES, I.; RODRIGUES, J.A.S. Valor nutricional de híbridos de sorgo com capim-sudão em comparação ao de outros volumosos utilizados no período de baixa disponibilidade das pastagens. Arquivos Brasileiro de Medicina Veterinária e Zootecnia, Belo Horizonte, v. 58, n.6, p.1249-1252, 2006.

VIANA, A.C., RIBAS, P.M.; MIRANDA, J.E.C. Manejo cultura do sorgo forrageiro. In: CRUZ, J.C., PEREIRA FILHO, I.A., RODRIGUES, J.A.S. Produção e utilização de silagem de milho e sorgo. Embrapa Milho e Sorgo, Sete Lagoas. 2001, p.263-287. 